\title{
PEMBELAJARAN INKLUSIF GENDER MELALUI METODE CARD SHORT DI MADRASAH IBTIDAIYAH
}

\author{
Oleh; Sarifa Suhra \\ Dosen tetap pada jurusan Tarbiyah Sekolah Tinggi Agama Islam Negeri (STAIN) Watampone \\ e-mail: syarifah_suhra@yahoo.com
}

\begin{abstract}
:
This paper discusses Gender inclusive learning through the application of Short card method in Madrasah Ibtidaiyah. Card Short is a collaborative activity that can be used to teach concepts, classifications of properties, facts about an object or review of science that has been given before or repeated information. The dominant physical movement in this method can help be dynamic tired class that can eliminate boredom and enable students to learn together.

Gender-inclusive learning in Madrasah Ibtidaiyah implies that in order to involve students in tapping learning materials that have broad sections or categories, the teacher writes the material and its parts into cardboard or others separately. Paper is scrambled and each student is evenly distributed then the teacher gives the card to each student regardless of the social status and gender of the students are all given the opportunity to get involved together in learning
\end{abstract}

\section{Abstrak:}

Tulisan ini membahas tentang Pembelajaran inklusif Gender melalui penerapan Metode card short di Madrasah Ibtidaiyah. Card Short (sortir kartu) merupakan kegiatan kolaboratif yang bisa digunakan untuk mengajarkan konsep, penggolongan sifat, fakta tentang suatu objek atau mereview ilmu yang telah diberikan sebelumnya atau mengulangi informasi. Gerakan fisik yang dominan dalam metode ini dapat membantu mendinamiskan kelas yang kelelahan hingga dapat menghilangkan kebosanan dan mengaktifkan siswa dalam belajar bersama.

Pembelajaran inklusif gender di Madrasah Ibtidaiyah mengandung arti bahwa untuk melibatkan siswa dalam menelah materi pembelajaran yang memiliki bagian-bagian atau kategori yang luas, guru menuliskan materi dan bagian-bagiannya ke dalam kertas karton atau yang lainnya secara terpisah. Kertas diacak dan setiap siswa secara merata lalu guru memberikan kartu kepada setiap siswa tanpa membedakan status sosial dan jenis kelamin siswa semua diberi kesempatan terlibat bersama dalam belajar.

\section{Kata kunci: pembelajaran, inklusif gender, metode, card short, Madrasah Ibtidaiyah}

\section{PENDAHULUAN}

Sebuah adigum mengatakan bahwa "al-Thariqat Ahamm Min al-Maddah" (metode jauh lebih penting dibanding materi), adalah sebuah realita bahwa cara penyampaian yang komunikatif lebih disenangi oleh peserta didik walaupun materi yang disampaikan sesungguhnya tidak terlalu menarik. Sebaliknya materi cukup baik, karena disampaikan dengan cara yang kurang menarik maka materi itu sendiri kurang dapat dicerna oleh peserta didik. Oleh karena itu 
penerapan metode yang tepat sangat mempengaruhi pencapaian keberhasilan dalam proses pembelajaran. Metode yang tidak tepat akan berakibat terhadap pemakaian waktu yang tidak efisien.

Penggunaan metode dalam satu mata pelajaran bisa lebih dari satu macam (bervariasi). Metode $^{1}$ yang variatif dapat membangkitkan motivasi belajar anak didik. Dalam pemilihan dan penggunaan sebuah metode harus mempertimbangkan evektivitas dan relevansinya dengan materi yang disampaikan. Seiring dengan itu, seorang pendidik/ guru dituntut agar cermat memilih dan menetapkan metode.

Mengajar yang dalam bahasa Inggrisnya disebut teaching, dapat diartikan sebagai upaya memberikan wawasan kognitif pada peserta didik sebagai bagian dari membangun wawasan tentang sesuatu dalam rangkan menumbuhkan kemampuan afektif dan psikomotorik pada peserta didik. Dengan demikian, pembelajaran lebih merupakan alat dalam rangka memperkaya wawasan serta menumbuhkan penghayatan dan pengalaman yang benar, dan kokoh antara lain harus disertai dengan pemahaman dan wawasan yang benar yang dihasilkan melalui kegiatan pembelajaran. Hal ini akan terjadi apabila pembelajaran tersebut dilakukan secara benar, efektif dan efisien dan ditunjukkan bukan semata-mata untuk memahami sebuah konsep atau teori, melainkan dilanjutkan dengan menghayati dan mengamalkannya. ${ }^{2}$ Sejauh ini kegiatan pembelajaran yang berlangsung di lembaga-lembaga Pendidikan formal didomiasi pandangan bahwa pengetahuan sebagai seperangkat fakta-fakta harus dihafalkan, sehingga kegiatan belajar mengajar berfokus pada guru sebagai sumber belajar. Belajar dirasakan sebagai tekanan dan beban, serta materi yang telah dipelajari mudah dilupakan dan tidak bermakna bagi siswa.

${ }^{1}$ Fungsi dari metode itu sendiri adalah mengantarkan suatu tujuan kepada obyek sasaran dengan cara yang sesuai dengan perkembangan obyek sasaran tersebut. Dalam al-Qur'an, metode dikenal sebagai sarana yang menyampaikan seseorang kepada tujuan penciptaannya sebagai khalifah di muka bumi dengan melaksanakan pendekatan, di mana manusia ditempatkan sebagai makhluk yang memiliki potensi rohaniah dan jasmaniah yang keduanya dapat digunakan sebagai saluran penyampaian materi pelajaran. Menurut Hasan Langgulung bahwa penggunaan metode di dasarkan atas tiga aspek pokok, yaitu : 1). Sifat-sifat dan kepentingan yang berkenaan dengan tujuan utama pendidikan Islam, yaitu pembinaan manusia mukmin yang mengaku sebagai hamba Allah. 2). Berdasarkan dengan metode-metode yang betul-betul berlaku yang disebutkan dalam al-Qur'an atau disimpulkan dari padanya. 3). Membicarakan tentang pergerakan (motivation) dan disiplin dalam Istilah al-Qur'an disebut ganjaran (sawab) dan hukuman (iqab). Lihat Abuddin Nata, Filsafat Pendidikan Islam, Jilid 1 (Cet. I; Jakarta: Logos Wacana Ilmu, 1997), h. 94 Lihat pula Ramayulis, Metodologi Pengajaran Agama Islam Cet. III; Jakarta: Kalam Mulia, 2001, h. 78

${ }^{2}$ Abuddin Nata, Perspektif Islam tentang Strategi Pembelajaran (Cet. I; Jakarta: Kencana Prenada Media Group, 2009), h. 175. 
Akibatnya semakin tinggi jenjang pendidikan semakin tinggi materi pembelajaran yang tidak dipahami. Salah satu komponen penting dalam kegiatan belajar mengajar adalah guru.

Guru mempunyai peranan ganda sebagai pengajar dan pendidik dalam proses pembelajaran. Tugas utama guru adalah membantu perkembangan intelektual, efektif dan psikomotor pelajar melalui menyampaikan pengetahuan, pemecahan masalah, latihan-latihan efektif dan keterampilan. Guru sebagai pendidik membantu mendewasakan anak secara psikologis, sosial dan moral. Selain sebagai pengajar dan pendidik mempunyai tanggungjawab dalam kegiatan pembelajaran oleh karena itu guru mempunyai peran yang sangat besar dalam mengolah kelas.

Seperti diketahui metode pembelajaran yang pada umumnya dilakukan oleh sekolah adalah metode pembelajaran yang lebih menekankan transmisi keilmuan klasik, yang memungkinkan adanya penerimaan imu secara bulat (taken forgranted) yang tak terbantahkan, yang memberii ruang gerak yang sempit bagiadanya dialog dan diskusi kritis. Sementara itu, persoalan gender sarat dengan problematik-problematik kultural yang sulit diselesaikan tanpa adanya dialog dan diskusi-diskusi. Metode pembelajaran ini, jika diterapkan apa adanya, jelas tidak akan membuahkan hasil yang baik. Oleh sebab itu harus diupayakan kesempatan untuk terjadinya dialog dan diskusi-diskusi, agar konsep-konsep penting pendidikan gender dapat lebih mudah tercerap oleh para siswa.

Salah satu metode pembelajaran yang dapat meningkatkan prestasi siswa, membuat siswa aktif, bahkan siswa belajar sambil bermain adalah menggunakan metode Card Short, metode ini diterapkan dengan menggunakan media kartu dalam praktek pembelajaran, akan membantu siswa dalam memahami pelajaran dan menumbuhkan motivasi mereka dalam pembelajaran, sebab dalam penerapan metode Card Short, guru hanya berperan sebagai fasilitator, yang memfasilitasi siswanya dalam pembelajaran, sementara siswa belajar secara aktif dengan fasilitas dan arahan dari guru. Card Sort yaitu motivasi dari guru; bagi kartu kosong secara acak; guru mencari kata kunci di papan; siswa mencari kata sejenis (satu tema) dengan temannya; diskusi kelompok berdasarkan temanya; menyusun kartu di papan dan masing-masing kelompok mempresentasikan hasilnya.

\section{PEMBAHASAN}

\section{A. Pengertian Metode Card short}


Card Short bisa disebut sortir kartu yaitu pemilahan kartu. Metode ini merupakan kegiatan kolaboratif yang bisa digunakan untuk mengajarkan konsep, karakteristik, klasifikasi, fakta, tentang obyek atau mereview informasi. Gerakan fisik yang dominan dalam strategi ini dapat membantu mendinamiskan kelas yang jenuh dan bosan.

Card Short yakni strategi pembelajaran berupa potongan-potongan kertas yang dibentuk seperti kartu yang berisi informasi atau materi pelajaran. Pembelajaran aktif model Card Short merupakan pembelajaran yang menekankan keaktifan siswa, dimana dalam pembelajaran ini setiap siswa diberi kartu indeks yang berisi informasi tentang materi yang akan dibahas, kemudian siswa mengelompok sesuai dengan kartu indeks yang dimilikinya. Setelah itu siswa mendiskusikan dan mempresentasikan hasil diskusi tentang materi dari kategori kelompoknya. Di sini pendidik lebih banyak bertindak sebagai fasilitator dan menjelaskan materi yang perlu dibahas atau materi yang belum dimengerti siswa setelah presentasi selesai. Card Short (sortir kartu) strategi ini merupakan kegiatan kolaboratif yang bisa digunakan untuk mengajarkan konsep, penggolongan sifat, fakta tentang suatu objek atau mereview ilmu yang telah diberikan sebelumnya atau mengulangi informasi. Gerakan fisik yang dominan dalam strategi ini dapat membantu mendinamisir kelas yang kelelahan.

Card Sort (mensortir kartu) yaitu suatu strategi yang digunakan pendidik dengan maksud mengajak peserta didik untuk menemukan konsep dan fakta melalui klasifikasi materi yang dibahas dalam pembelajaran. Card short juga merupakan metode pembelajaran dengan cara menyortir kartu yang acak bertujuan mengaktifkan setiap individu sekaligus kelompok dalam belajar. $^{3}$

Strategi ini dapat diterapkan apabila guru hendak menyajikan materi atau topik pembelajaran yang memiliki bagian-bagian atau kategori yang luas. Caranya guru menuliskan materi dan bagian-bagiannya ke dalam kertas karton atau yang lainnya secara terpisah. Kertas diacak dan setiap siswa diberikan kesempatan untuk mengambil satu kertas, atau beberapa siswa mengambil kertas tersebut lalu membagikannya satu persatu pada teman-temannya. Setelah siswa memegang kertas tersebut, kemudian mencari pasangan siswa lain dalam kelompok berdasarkan kategori yang tertulis. Jika seluruh siswa sudah dapat menemukan pasangannya

${ }^{3}$ Ismail, SM. Strategi Pembelajaran Agama Islam Berbasis PAIKEM. (Cet. I; Semarang: RaSail Media Grup, 2008), h. 89 
berdasarkan kategori yang tepat, mintalah mereka berjajar secara urut kemudian salah satu menjelaskan kategori kelompoknya.

Salah satu ciri dalam metode Card Short yaitu pendidik lebih banyak bertindak sebagai fasilitator dan menjelaskan materi yang perlu dibahas atau materi yang belum dimengerti siswa setelah presentasi selesai. Sehingga materi yang telah dipelajari benar-benar difahami dan dimengerti oleh siswa. Ciri khas dari pembelajaran aktif model Card Short ini adalah siswa mencari bahan sendiri atau materi yang sesuai dengan kategori kelompok yang diperolehnya dan siswa mengelompok sesuai kartu indeks yang diperolehnya. Dengan demikian siswa menjadi aktif dan termotivasi dalam proses belajar mengajar.

\section{B. Tujuan Metode Card Sort}

Tujuan dari strategi dan metode belajar menggunakan Card Short ini adalah untuk mengungkapkan daya ingat terhadap materi pelajaran yang telah dipelajari siswa. Tujuan dari strategi dan metode belajar menggunakan "memilah dan memilih kartu Card Short ini adalah untuk mengungkapkan daya ingat atau recall terhadap materi pelajaran yang telah dipelajari siswa. Sehingga siswa benar-benar memahami dan mengingat pelajaran yang telah diberikan.

\section{Aplikasi/Langkah-langkah Metode Card Sort}

Melvin L. Silberman menjelaskan bahwa mengajarkan bukan semata persoalan menceritakan. Belajar bukanlah konsekuensi dari penuangan informasi ke dalam benak siswa. Belajar memerlukan keterlibatan mental dan kerja siswa sendiri. Penjelasan dan pemeragaan semata tidak akan membuahkan hasil belajar yang langgeng. Pola belajar yang bisa membuahkan hasil belajar yang langgeng hanyalah kegiatan belajar aktif, agar belajar menjadi aktif siswa harus mengerjakan banyak sekali tugas. Mereka harus menggunakan otak, mengkaji gagasan, memecahkan masalah, dan menerapkan apa yang mereka pelajari. Belajar aktif harus gesit, menyenangkan, bersemangat dan penuh gairah. Siswa bahkan sering meninggalkan tempat duduk mereka, bergerak leluasa dan berfikir keras (moving about and thinking aloud). Melvin L Siberman ${ }^{4}$ mengemukakan langkah-langkah metode Card Sort sebagai berikut:

1) Masing-masing siswa diberikan kartu indeks yang berisi materi pelajaran. Kartu indeks dibuat berpasangan berdasarkan definisi, kategori/kelompok, misalnya kartu yang berisi

${ }^{4}$ Melvin L Siberman, Active Learning: 101 Cara Belajar Siswa Aktif, diterjemahkan oleh Raisul Muttaqien, (Cet. XI; Bandung: Nuansa Cendikia, 2016), h. 169-170 
aliran empiris dengan kartu pendidikan ditentukan oleh lingkungan dan lain-lain. Makin banyak siswa makin banyak pula pasangan kartunya.

2) Guru menunjuk salah satu siswa yang memegang kartu, siswa yang lain diminta berpasangan dengan siswa tersebut bila merasa kartu yang dipegangnya memiliki kesamaan definisi atau kategori.

3) Agar situasinya agak seru dapat diberikan hukuman bagi siswa yang melakuan kesalahan. Jenis hukuman dibuat atas kesepakatan bersama.

4) Guru dapat membuat catatan penting di papan tulis pada saat prosesi terjadi.

\section{Kelebihan dan kelemahan metode Card Short}

a. Kelebihan

1) Guru mudah menguasai kelas

2) Mudah dilaksanakan

3) Mudah mengorganisir kelas

4) Dapat diikuti oleh siswa yang jumlahnya banyak

5) Mudah menyiapkannya

6) Guru mudah menerangkan dengan baik

b. Kelemahan

Adanya kemungkinan terjadi penyimpangan perhatian murid, terutama apabila terjadi jawaban-jawaban yang menarik perhatiannya, padahal bukan sasaran (tujuan) yang diinginkan dalam arti terjadi penyimpangan dari pokok persoalan semula.

\section{E. Pembelajaran Inklusif gender di Madrasah Ibtidaiyah}

Disadari atau tidak doktrin patriarki dalam sistem tradisi masyarakat Indonesia telah berakar kuat di alam bawah sadar setiap orang termasuk peserta didik, oleh karena itu untuk melakukan upaya penyadaran maka diperlukan berbagai strategi salah satunya melalui pendidikan khususnya penerapan metode pembelajaran yang memuat nilai-nilai kesetaraan gender. Berkaitan dengan hal tersebut metode pembelajaran kooperatif tipe NHT merupakan salah satu alternative pilihan yang tepat karena metode tipe ini mengandung aspek kesetaraan gender. 
Gender adalah pembedaan peran, fungsi dan tanggung jawab antara perempuan dan lakilaki yang dihasilkan dari konstruksi sosial budaya dan dapat berubah sesuai dengan perkembangan zaman. ${ }^{5}$ Secara etimologis gender berasal dari kata gender yang berarti jenis kelamin. ${ }^{6}$ Tetapi Gender merupakan perbedaan jenis kelamin yang bukan disebabkan oleh perbedaan biologis dan bukan kodrat Tuhan, melainkan diciptakan baik oleh laki-laki maupun perempuan melalui proses sosial budaya yang panjang. Perbedaan perilaku antara pria dan wanita, selain disebabkan oleh faktor biologis sebagian besar justru terbnetuk melalu proses sosial dan cultural. Oleh karena itu gender dapat berubah dari tempat ketempat, waktu ke waktu, bahkan antar kelas sosial ekonomi masyarakat. ${ }^{7}$ Dalam batas perbedaan yang paling sederhana, seks dipandang sebagai status yang melekat atau bawaan sedangkan gender sebagai status yang diterima atau diperoleh. Mufidah dalam Paradigma Gender ${ }^{8}$ mengungkapkan bahwa pembentukan gender ditentukan oleh sejumlah faktor yang ikut membentuk, kemudian disosialisasikan, diperkuat, bahkan dikonstruksi melalui sosial atau kultural, dilanggengkan oleh interpretasi agama dan mitos-mitos seolah-olah telah menjadi kodrat laki-laki dan perempuan.

Gender merupakan analisis yang digunakan dalam menempatkan posisi setara antara lakilaki dan perempuan untuk mewujudkan tatanan masyarakat sosial yang lebih egaliter. Jadi, gender bisa dikategorikan sebagai perangkat operasional dalam melakukan measure (pengukuran) terhadap persoalan laki-laki dan perempuan terutama yang terkait dengan pembagian peran dalam masyarakat yang dikonstruksi oleh masyarakat itu sendiri. Gender bukan hanya ditujukan kepada perempuan semata, tetapi juga kepada laki-laki. Hanya saja, yang dianggap mengalami posisi termarginalkan sekarang adalah pihak perempuan, maka perempuanlah yang lebih ditonjolkan dalam pembahasan untuk mengejar kesetaraan gender yang telah diraih oleh laki-laki beberapa tingkat dalam peran sosial, terutama di bidang pendidikan karena bidang inilah diharapkan dapat mendorong perubahan kerangka berpikir, bertindak, dan berperan dalam berbagai segmen kehidupan sosial. Analisis gender diharuskan ada dalam setiap terjadi ketimpangan sosial dan kesenjangan jender akibat adanya pemahaman masyarakat yang bias gender. Berbagai bentuk kesenjangan gender yang terjadi dalam berbagai bidang kehidupan

\footnotetext{
${ }^{5}$ Mufidah Chalid, Bingkai Sosial Gender: Islam, Strukturasi dan Konstruksi Sosial, (Malang: UIN Maliki Press, 2010), h. 5

${ }^{6}$ Jhon M. Echol, dan Hasan Shadily, Kamus Besar Inggris-Indonesia, (Cet. XXIII; Jakarta : Gramedia Pustaka Utama, 1996), h, 234

${ }^{7}$ Mansour Faqih, Gender Sebagai Alat Analisis Sosial, (edisi 4 November 1996).

${ }^{8}$ Mufidah Ch, Paradigma Gender, (Malang: Bayumedia Publishing, 2003), h. 4-6.
} 
masyarakat, terpresentasi juga dalam dunia pendidikan. Bahkan proses dan institusi pendidikan dipandang berperan besar dalam mensosialisasikan dan melestrikan nilai-nilai dan cara pandang yang mendasari munculnya berbagai ketimpangan gender dalam masyarakat.

Pembelajaran inklusif gender di Madrasah Ibtidaiyah mengandung arti bahwa untuk melibatkan siswa dalam menelah materi yang tercakup dalam suatu pelajaran tersebut, sebagai gantinya mengajukan pertanyaan kepada seluruh siswa di kelas. Teknik ini memberikan kesempatan pada siswa untuk meningkatkan kemampuan baru, baik kemampuan dalam aspek pengetahuan, berbicara. Sikap maupun keterampilan psikomotorik siswa. Metode ini dapat diterapkan apabila guru hendak menyajikan materi atau topik pembelajaran yang memiliki bagian-bagian atau kategori yang luas. Caranya guru menuliskan materi dan bagian-bagiannya ke dalam kertas karton atau yang lainnya secara terpisah. Kertas diacak dan setiap siswa secara merata tanpa membedakan status sosialnya dan jenis kelaminnya diberikan kesempatan untuk mengambil satu kertas, atau beberapa siswa mengambil kertas tersebut lalu membagikannya satu persatu pada teman-temannya. Setelah siswa memegang kertas tersebut, kemudian mencari pasangan siswa lain dalam kelompok berdasarkan kategori yang tertulis. Jika seluruh siswa sudah dapat menemukan pasangannya berdasarkan kategori yang tepat, mintalah mereka berjajar secara urut kemudian salah satu menjelaskan kategori kelompoknya.

Salah satu wujud pemenuhan atas hak dan kewajiban setiap individu adalah pendidikan. Dalam term agama, pemenuhan kebutuhan akal dan spiritual dapat dilakukan dengan belajar untuk mendapatkan pengetahuan sebagai jalan untuk memahami agama dan membangun dunia. Pendidikan dan menuntut ilmu dalam Islam menjadi sebuah keharusan. Dalam ayat yang pertama kali turun yaitu surat al-Alaq disebutkan kata Iqra' yang mempunyai makna membaca. Perintah ini menyiratkan pentingnya belajar melalui membaca untuk memahami semua fenomena yang ada di dunia. Nabi Muhammad SAW juga menegaskan kembali tentang kewajiban untuk mencari ilmu tanpa membedakan jender yaitu "talab al-ilmi faridatun 'ala kulli muslimun wa muslimatin". 9 Jadi pendidikan itu secara inklusif diperuntukkan untuk laki-laki dan perempuan. Karena pada dasarnya dalam islam, ilmu adalah suci dan mencari ataupun menuntutnya adalah hak dan kewajiban bagi siapapun (laki-laki dan perempuan) tanpa adanya perbedaan.

${ }^{9}$ Muhammad. Attiyah al-Abrashi, al Tarbiyah al-Islamiyah, (Mesir: IsaBabi al Halabi, t.t), h. 109. 
Attiyah al-Abrashi adalah salah seorang tokoh yang concern dalam dunia pendidikan. Kurang lebih duapuluhan karyanya berbicara tentang pendidikan dan konsep pendidikan dalam perspektif Islam. Salah satu kajian menarik yang dipaparkan oleh 'Attiyah adalah masalah pendidikan kebebasan dan kesetaraan. Bagi 'Attiyah wacana kebebasan pendidikan atau "altarbiyah istiqlaliyah" tersirat makna kesetaraan untuk mendapatkan hak pendidikan. Dalam term lain secara khusus 'Attiyah juga mengupas tentang pentingnya pendidikan bagi kaum perempuan. ${ }^{10} \mathrm{Hal}$ ini didasarkan pada historistas perkembangan Islam itu sendiri yang memang tidak menafikan peran perempuan dari masa ke masa. Salah satu bagian penting dalam pembelajaran yang harus menjadi sorotan adalah metode pembelajaran. Metode pembelajaran bermakna segala segi kegiatan yang terarah yang dikerjakan oleh guru dalam rangka kemestian mata pelajaran yang diajarkannnya, ciri-ciri perkembangan muridnya, suasana alam sekitarnya dan tujuan menolong siswa untuk mencapai proses belajar mengajar yang dinginkan dan perubahan yang dikehendaki pada tingkah laku mereka serta menolong mereka untuk memperoleh maklumat, pengetahuan, kebiasaan, sikap, minat dan nilai-nilai yang diinginkan. ${ }^{11}$

Dengan demikian aspek gender dalam penerapan metode card short terletak pada langkah penerapannya yang mengharuskan pembentukan kelompok sebelum pelaksanaannya. Pembentukan kelompok didasarkan pada beberapa aspek salah satunya adalah diharuskan pada setiap kelompok terdapat perbedaan jenis kelamin artinya tiap-tiap kelompok selama memungkinkan harus terdiri dari dua jenis kelamin berbeda dan diakomodir dalam kelompok secara adil dan tidak boleh dimonopoli satu jenis kelamin saja dalam setiap kelompok. Dalam proses selanjutnya guru memperlakukan semua siswanya sama, baik dalam hal penunjukan untuk menjawab pertanyaan yang diberikan maupun kesempatan memberi tanggapan termasuk dalam pemberian contoh guru melibatkan setiap siswa tanpa memandang jenis kelamin. Demikian juga dalam penjelasan materi guru harus memperlakukan manusia laki-laki dan perempuan secara adil kapanpun dan dimanapun.

\section{PENUTUP}

Bagian penutup ini berisi kesimpulan sebagai berikut:

\footnotetext{
${ }^{10}$ Muhammad 'Attiyah al-Abrashi, al-Tarbiyah wa Falasifatuha (Bairut: Dar al Fikr, 1969), h. 115

${ }^{11}$ Omar Muhammad al-Thoumy al-Syaibany, Falsafat al-Tarbiyat al-Islamiyah diterjemahkan oleh Hasan Langgulung Falsafah Pendidikan Islam (Cet. III; Jakarta: Bulan Bintang, 1979), h. 399.
} 
1. Card Short (sortir kartu) merupakan kegiatan kolaboratif yang bisa digunakan untuk mengajarkan konsep, penggolongan sifat, fakta tentang suatu objek atau mereview ilmu yang telah diberikan sebelumnya atau mengulangi informasi. Gerakan fisik yang dominan dalam metode ini dapat membantu mendinamisir kelas yang kelelahan hingga dapat menghilangkan kebosanan dan mengaktifkan siswa dalam belajar bersama.

2. Pembelajaran inklusif gender di Madrasah Ibtidaiyah mengandung arti bahwa untuk melibatkan siswa dalam menelah materi pembelajaran yang memiliki bagian-bagian atau kategori yang luas, guru menuliskan materi dan bagian-bagiannya ke dalam kertas karton atau yang lainnya secara terpisah. Kertas diacak dan setiap siswa secara merata tanpa membedakan status sosial dan jenis kelamin semua siswa diberikan kesempatan sama untuk mengambil satu kertas, atau beberapa siswa mengambil kertas tersebut lalu membagikannya satu persatu pada teman-temannya. metode ini memberikan kesempatan pada siswa untuk meningkatkan kemampuan baru, baik kemampuan dalam aspek pengetahuan, berbicara. Sikap maupun keterampilan psikomotorik siswa.

\section{DAFTAR RUJUKAN}

al-Abrashi, al Tarbiyah al-Islamiyah, Mesir: IsaBabi al Halabi, t.t.

-------, Muhammad 'Attiyah. al-Tarbiyah wa Falasifatuha Bairut: Dar al Fikr, 1969

Chalid, Mufidah Bingkai Sosial Gender: Islam, Strukturasi dan Konstruksi Sosial, Malang: UIN Maliki Press, 2010

--------, Paradigma Gender, (Malang: Bayumedia Publishing, 2003.

Echol, Jhon M. dan Hasan Shadily, Kamus Besar Inggris-Indonesia, Cet. XXIII; Jakarta : Gramedia Pustaka Utama, 1996

http://garasikeabadian.blogspot.co.id/2013/03/gender-dalam-pendidikan.html Gender dalam Pendidikan Islam, diakses pada tanggal 20 April 2016

Ismail, SM. Strategi Pembelajaran Agama Islam Berbasis PAIKEM. Cet. I; Semarang: RaSail Media Grup, 2008

Mansour Faqih, Gender Sebagai Alat Analisis Sosial, edisi 4 November 1996.

Nata, Abuddin Perspektif Islam tentang Strategi Pembelajaran Cet. I; Jakarta: Kencana Prenada Media Group, 2009

--------, Filsafat Pendidikan Islam, Jilid 1 Cet. I; Jakarta: Logos Wacana Ilmu, 1997

Ramayulis, Metodologi Pengajaran Agama Islam Cet. III; Jakarta: Kalam Mulia, 2001

Siberman, Melvin L. Active Learning: 101 Cara Belajar Siswa Aktif, diterjemahkan oleh Raisul Muttaqien, Cet. XI; Bandung: Nuansa Cendikia, 2016. 
Syaibany, Omar Muhammad al-Thoumy. Falsafat al-Tarbiyat al-Islamiyah diterjemahkan oleh Hasan Langgulung Falsafah Pendidikan Islam Cet. III; Jakarta: Bulan Bintang, 1979 